\title{
Genetics and epigenetics of alcohol dependence
}

\author{
Vanessa Nieratschker ${ }^{*}$, Anil Batra and Andreas J Fallgatter
}

\begin{abstract}
Alcohol dependence is a severe and common disorder associated with high morbidity and mortality rates. Genetic as well as environmental factors are known to modulate susceptibility to alcohol dependence. There is a growing body of evidence suggesting that this interaction between the genome and the environment is mediated by epigenetic mechanisms, e.g. DNA methylation at CpG sites. Following an introduction of epigenetic regulation of gene transcription, this review will provide an overview over recent genetic and epigenetic findings in the context of alcohol dependence focusing on human studies. Finally, we will discuss the current limitations of epigenetic studies as well as the implications of genetic and epigenetic findings for the development of better treatment and prevention strategies.
\end{abstract}

Keywords: Genetics, Gene * environment interaction, Epigenetics, DNA methylation, Alcohol dependence, Homocysteine, Withdrawal, Candidate gene studies, Genome-wide studies

\section{Introduction}

Alcohol dependence is a severe disorder which contributes substantially to the global burden of disease. According to the World Health Organization (WHO) 2 billion individuals worldwide consume or abuse alcohol. Alcohol consumption accounts for $3.2 \%$ of all deaths worldwide, as well as for $4 \%$ of Disability Adjusted Life Years (DALYs) which are expressed as the number of years lost due to ill-health, disability, or early death (WHO, 2002). Despite the deleterious effects of chronic alcohol consumption, efficacy of preventive and therapeutic strategies still needs to be optimized.

The heritability of alcohol dependence is well recognized and heritability estimates range between 40 and $70 \%$ [1-4]. However, the effects of the genetic risk variants for psychiatric disorders, including alcohol dependence, identified so far are small, and even after consideration of polygenetic contributions they explain only a small fraction of the estimated heritability of psychiatric disorders. One possible explanation for this "missing heritability" [5] might be the interaction between genes and environment mediated by epigenetic mechanisms.

The aim of this review is to provide an overview of recent human studies and to summarize and discuss the

\footnotetext{
* Correspondence: vanessa.nieratschker@med.uni-tuebingen.de Department of Psychiatry and Psychotherapy, University of Tuebingen, Germany, Calwerstrasse 14, Tuebingen 72076, Germany
}

role and importance of genetic and epigenetic factors in alcohol dependence.

\section{Epigenetic mechanisms}

Epigenetic mechanisms lead to functionally relevant modifications of the genome as they induce stable changes in gene expression which consequently influence the phenotypic outcome. These transcriptional control mechanisms, which can be heritable, are not accompanied by nucleotide changes in the underlying DNA sequence. Epigenetic mechanisms include histone modifications, activities of noncoding RNA, and chemical alterations of the DNA molecule itself. While the involvement of DNA methylation in transcriptional regulation is a long known phenomenon [6], the distinct role of 5hydroxymethylation in this process still has to be investigated [7-9]. In this review, we will focus on the role of DNA methylation in epigenetic regulation of gene expression.

\section{DNA methylation}

DNA is methylated at position 5 of the cytosine pyrimidine ring by transfer of the methyl group from S-adenosyl methionine (SAM), a reaction catalyzed by DNA methyltransferases (DNMTs). DNA methylation is a stable chemical mark which is maintained through cycles of cell division. DNA methylation mainly takes place at $\mathrm{CpG}$ sites, nucleotide sequences consisting of a 
cytosine followed by a guanine. CpG sites can be found in low frequency throughout the genome, but are enriched in so called CpG islands, which are mainly found in the promoter regions of genes near the transcription start site. Promoter DNA methylation has been strongly correlated with gene silencing, as the chemical modification of the DNA is interfering with transcription factor binding and attracts methyl-binding domaincontaining proteins, such as methyl CpG binding protein 2 (MeCP2), which act as transcriptional repressors [10]. However, more recent studies suggest that the pattern of transcriptional regulation through DNA methylation is more complex than previously anticipated [11]. Traditionally it has been believed that DNA methylation patterns are important for cell fate determination and that they are fixed during embryonic development and cell differentiation and remain stable afterwards [6]. Today it is known that DNA methylation patterns are not as fixed as previously thought, but can be influenced by environmental factors and change over time [12]. Therefore, regulation of gene transcription through DNA methylation which is mediated by environmental stimuli plays a role in physiological responses as well as in adaptation of the genome to environmental requirements. Factors influencing DNA methylation are among others diet (e.g. [13]), chemicals (e.g. [14]), drugs of abuse (e.g. [15]), and even psychosocial factors like exposure to stress (e.g. [16]).

\section{Review}

We conducted a systematic literature search using NCBI PubMed (http://www.ncbi.nlm.nih.gov/pubmed/) and keywords related to genetics and epigenetics of alcohol abuse and dependence. Genome-wide association studies in the context of alcohol dependence have been identified using the Catalog of Published Genome-wide association studies (http://www.genome.gov/gwastudies/). We included studies published prior to April 2013 in our review. The reference sections of the chosen studies were reviewed to detect additional studies we might have missed in our literature search. Genetic studies, with a strong focus on genome-wide results, will be reviewed first, followed by a section on gene-environment interactions, and finally a review of epigenetic studies in the context of alcohol dependence. This part of the review will first summarize recent candidate-gene based approaches followed by a report of the results of the two epigenome-wide studies published to date. The last section of the review will discuss recent findings on epigenetics of alcohol withdrawal.

\section{Genetics and epigenetics of alcohol dependence}

The contribution of genetic factors to the development of alcohol dependence is high [1-4] but nevertheless, knowledge about the specific genes underlying alcohol dependence is currently very limited. The best classical candidate genes for alcohol dependence are alcohol dehydrogenase $(A D H)$ and aldehyde dehydrogenase $(A L D H)$ [17]. Both genes are involved in enzymatic degradation of alcohol. Recently, the first genome-wide association studies (GWAS) on alcohol dependence have been published [18-29].

These studies revealed some interesting new candidate genes for alcohol dependence including cadherin 11 (CDH11) [22] and cadherin 13 (CDH13) [22,25], GATA binding protein 4 (GATA4) [25], solute carrier family 22, member 18 (SLC22A18) [19], and potassium large conductance calcium-activated channel, subfamily M, alpha member 1 gene (KCNMA1) [23]. Moreover, they provided further evidence for an association between $A D H$ and $A L D H$ and alcohol dependence [20,23,25].

Results of a recent study by Yan et al. [30] investigating the predictive value of the cumulative impact of multiple genetic variants identified in previous candidate as well as genome-wide studies, support a polygenic model for alcohol dependence. This polygenic model of inheritance involves many genetic variants of small effects to contribute to the risk of alcohol dependence. Similar models of inheritance have been found for schizophrenia and bipolar disorder [31] and might apply to many other common complex diseases. However, this study also showed that a positive family history of alcohol dependence was a better predictor for alcohol dependence than the sum of genetic risk variants. This finding illustrates that the genetic risk variants identified so far can only explain a small fraction of the heritability of alcohol dependence.

One possible explanation for this phenomenon of "missing heritability" [5] is that beside the genome itself, the cross-talk between the genome and the environment is implicated in the etiology of alcohol dependence. Gene-environment interactions have been reported for the serotonin transporter (5-HTT) [32-35], the dopamine receptor (DRD2)/ankyrin repeat and kinase domain containing 1 (ANKK1) [36-38], catechol-O -methyltransferase (COMT) [39,40], monoamine oxidase $(M A O A)$ [41-43], $\mathrm{GABA}_{\mathrm{A}}$ receptor (GABRA2) [44], corticotrophin releasing hormone receptor 1 (CRHR1) [45-48].

Gene-environment interactions can be mediated by epigenetic mechanisms and evidence is emerging that alcohol consumption is one environmental factor which may alter epigenetic signatures and thus related gene expression levels. Altered gene expression in brain reward regions after alcohol intake has been reported, which suggests that individual genes are differentially regulated following alcohol consumption [49]. In actively drinking individuals, or individuals in early stages of alcohol 
abstinence, increased levels of homocysteine have been found [50-54]. Homocysteine plays an important role in DNA methylation as it is metabolized to methionine, which is then activated to S-adenosyl methionine (SAM) by ATP $[55,56]$. SAM is the most important methyl group donor in transmethylation reactions in vertebrates, including DNA methylation. Consequently, elevated homocysteine levels have been found to be associated with increased levels of global as well as gene-specific DNA methylation in alcohol dependent patients [57,58]. In contradiction to this finding in alcohol dependent patients, other studies investigating human subjects reported DNA hypomethylation to be associated with hyperhomocysteinemic states [59-63].

Alterations in promoter DNA methylation levels in alcohol dependent patients have been reported for homocysteine-induced ER protein (HERP), alpha synuclein $(S N C A)$, vasopressin $(A V P)$, nerve growth factor $(N G F)$, atrial natriuretic peptide $(A N P)$, N-methyl-D-aspartate $2 \mathrm{~b}$ receptor subtype (NR2B), MAOA, 5-HTT, $\mu$-opioid receptor (OPRM1), prodynorphin $(P D Y N)$, proopiomelanocortin $(P O M C)$, dopamine transporter $(D A T)$ [64-75].

While some of these studies reported hypermethylation in alcohol dependent patients (e.g. $[64,66,67,70,71]$ ), other reported a hypomethylation of the gene region investigated (e.g. [65,71]).

Recently, Zhang et al., [76] published an array-based study investigating methylation levels of $384 \mathrm{CpGs}$ in 82 candidate genes. The candidate genes have been selected based on their involvement in brain neurotransmission systems (dopaminergic, opiodergic, serotonergic, GABAergic/glutamatergic, cholinergic and cannabinoidergic), in alcohol metabolism, DNA methylation, or in signal transduction for alcohol reward and reinforcement, or they have been found associated with alcohol dependence in previous genetic studies. CpGs in gamma-aminobutyric acid receptor subunit beta-3 (GABRB3), pro-opiomelanocortin (POMC), neural cell adhesion molecule 1 (NCAM1), dopamine receptor D4 (DRD4), methyl-CpG-binding domain protein 3 (MBD3), 5-hydroxytryptamine receptor 3A (HTR3A) and 2B (HTR2B), and glutamate (NMDA) receptor subunit zeta-1 (GRIN1) were found to be differentially methylated in alcohol dependent patients compared to control subjects, but only the result for one CpG site in the promoter region of HTR3A withstood correction for multiple testing.

The same CpG site showed nonsignificantly higher methylation levels in a small replication sample, where only 6 CpGs in HTR3A have been investigated. To confirm this preliminary finding of differential methylation in $H T R 3 A$ in alcohol dependence, additional studies will be necessary.
While these studies concentrated on candidate genes, the first hypothesis free genome-wide investigations of the effect of alcohol on DNA methylation have been currently published:

Philibert et al. conducted a genome-wide study on the effect of recent alcohol use on the epigenome [77]. Here, the authors compared DNA methylation of females which did not consume alcohol in the last 6 months to methylation patterns of females consuming alcohol mildly (use of alcohol in between 1 and 8 weeks in the last 6 month), moderately (use of alcohol in between 9 and 25 weeks in the last 6 month), or heavily (alcohol use in every week in the last 6 month). By doing this, they found the overall degree of methylation to be (nonsignificantly) positively associated with the amount of alcohol consumed. When the moderate and heavy drinkers are pooled together and compared to the nonconsuming participants, a probe located in the active BCR-related $(A B R)$ gene, and in the $5^{`}$ untranslated region of the Bladder cancer-associated protein gene $(B L C A P)$ reached genome-wide significance after correction for multiple testing. However, only 4 of the heavy drinkers investigated met the criteria for a lifetime diagnosis of alcohol dependence, therefore this result needs further replication in a sample of alcohol dependent patients compared to control individuals.

The only epigenome-wide study investigating alcohol dependent subjects has been published by Zhang et al., early this year [78]. In contrast to Phillibert et al., Zhang et al., found the global methylation level, as well as the majority of significantly differentially methylated CpG sites, including the 50 most significant ones, to be hyopmethylated in patients compared to healthy controls. However, neither of these studies included a measurement of homocysteine levels, which would have been necessary to answer the question, whether DNA methylation on an epigenome-wide level is associated with the assumed elevated homocysteine levels in alcohol dependent patients.

Further studies addressing this question in a hypothesisfree genome-wide approach have to follow to clarify this issue as well as to elucidate the effects of alcohol dependence on the epigenome.

In addition to the elevated homocysteine levels in actively drinking individuals [50-54], during alcohol withdrawal, decreasing homocysteine levels have been observed [50,51,53,79]. Under the assumption that elevated homocysteine levels are associated with increased levels of DNA methylation in alcohol dependent patients $[57,58]$, a plausible hypothesis is that methylation levels also decrease during alcohol withdrawal. The first studies investigating the effects of alcohol withdrawal on DNA methylation have been conducted applying a candidate gene approach $[65,68,69]$. These studies reported 
conflicting results regarding the hypothesis of decreasing DNA methylation levels during alcohol withdrawal. Biermann et al., [65] found a decrease of $N R 2 B$ promoter methylation during withdrawal, although this decrease did not reach significance. In contrast to that, Heberlein et al., [68] investigating NGF, reported an increase in promoter methylation, and in our own study, we [69] did not detect an effect of alcohol withdrawal on $D A T$ promoter methylation.

\section{Conclusions}

There is a growing body of evidence highlighting the importance of genetic and epigenetic factors in the development and maintenance of alcohol dependence. Nonetheless, by investigating epigenetic factors in alcohol dependence, some limitations have to be kept in mind.

Most of the studies conducted thus far used peripheral tissue instead of brain samples, mostly because access to high quality brain material of well characterized alcohol dependent subjects is very limited. While this is not an issue in genetic studies, it might be a limitation in epigenetic research as epigenetic regulation is tissue- and cell-type specific. However, as alcohol acts not only on the brain but on the whole body, it could by hypothesized that there might be a significant overlap between methylation changes in the brain and blood, despite the cell-type specific nature of DNA methylation patterns. Moreover, the use of peripheral tissue is a valid approach as it is necessary for the identification of biomarkers with potential clinical usage. To identify those biomarkers, we need a material which is easily accessibly and can be studied in large samples of patients and control individuals. Peripheral blood is an adequate and convenient tissue for that purpose.

As the field of epigenetic research is relatively new, laboratory technologies still need to be optimized to provide an unbiased method which I) requires small amounts of input samples, II) is cost effective, and III) will be able to reliably detect epigenetic marks with single nucleotide resolution. In parallel with the improvement of laboratory techniques, new analytical methods and guidelines for quality control and analysis need to be developed. The novelty of epigenetic research in alcohol dependence also explains the relatively small number of studies published so far. In addition, a limited number of research groups currently conduct epigenetic studies in the field of alcohol dependence. The limitation of the data available could explain the still heterogeneous nature of the results regarding epigenetic effects of alcohol dependence and withdrawal. Furthermore, the literature is likely biased for positive associations, as negative findings are infrequently published. Therefore, further genetic and epigenetic research investigating large, homogenous groups of patients and controls which are matched as carefully as possible for confounding factors such as age, sex, smoking and other environmental factors potentially influencing epigenetic regulation are necessary. Despite the previously mentioned difficulties that need to be addressed in the near future, epigenetic studies have a great potential to contribute to a better understanding of the biological mechanisms underlying alcohol dependence. A deeper insight into the epigenetic regulation of alcohol dependence, withdrawal and relapse is needed to develop better treatment and prevention strategies. In addition, a better understanding of epigenetic regulation might help to detect individuals at a higher risk to develop alcohol dependence and/or identify alcohol dependent patients with a higher risk of relapse.

However, it has to be kept in mind that studies investigating epigenetics of withdrawal are currently very limited so conclusions should therefore be drawn with caution.

\section{Competing interests}

The authors declare that they have no competing interests.

\section{Authors' contribution}

VN conducted the literature search and drafted the manuscript, $A B$ and AJF participated in drafting the manuscript and provided critical revision of the manuscript. All authors read and approved the final manuscript.

Received: 15 May 2013 Accepted: 3 July 2013

Published: 11 July 2013

\section{References}

1. Agrawal A, Lynskey MT: Are there genetic influences on addiction: evidence from family, adoption and twin studies. Addiction 2008, 103:1069-1081.

2. Enoch MA, Goldman D: The genetics of alcoholism and alcohol abuse. Curr Psychiatr Rep 2001, 3:144-151.

3. Goldman D, Oroszi G, Ducci F: The genetics of addictions: uncovering the genes. Nat Rev Genet 2005, 6:521-532.

4. Lynskey MT, Agrawal A, Heath AC: Genetically informative research on adolescent substance use: methods, findings, and challenges. J Am Acad Child Adolesc Psychiatr 2010, 49:1202-1214

5. Manolio TA, Collins FS, Cox NJ, Goldstein DB, Hindorff LA, Hunter DJ, McCarthy MI, Ramos EM, Cardon LR, Chakravarti A, Cho JH, Guttmacher AE, Kong A, Kruglyak L, Mardis E, Rotimi CN, Slatkin M, Valle D, Whittemore AS, Boehnke M, Clark AG, Eichler EE, Gibson G, Haines JL, Mackay TF, McCarroll SA, Visscher PM: Finding the missing heritability of complex diseases. Nature 2009, 461:747-753.

6. Razin A, Riggs AD: DNA methylation and gene function. Science 1980, 210:604-610.

7. Tahiliani M, Koh KP, Shen Y, Pastor WA, Bandukwala H, Brudno Y, Agarwal S, lyer LM, Liu DR, Aravind L, Rao A: Conversion of 5-methylcytosine to 5-hydroxymethylcytosine in mammalian DNA by MLL partner TET1. science 2009, 324:930-935.

8. Kriaucionis $\mathrm{S}$, Heintz N: The nuclear DNA base 5-hydroxymethylcytosine is present in Purkinje neurons and the brain. Science 2009, 324:929-930.

9. Jin SG, Wu X, Li AX, Pfeifer GP: Genomic mapping of 5-hydroxymethylcytosine in the human brain. Nucleic Acids Res 2011, 39:5015-5024.

10. Jaenisch R, Bird A: Epigenetic regulation of gene expression: how the genome integrates intrinsic and environmental signals. Nat Genet 2003, 33(Suppl):245-254.

11. Jones PA: Functions of DNA methylation: islands, start sites, gene bodies and beyond. Nat Rev Genet 2012, 13:484-492. 
12. Ramchandani S, Bhattacharya SK, Cervoni N, Szyf M: DNA methylation is a reversible biological signal. Proc Natl Acad Sci USA 1999, 96:6107-6112.

13. Lillycrop KA, Burdge GC: Epigenetic mechanisms linking early nutrition to long term health. Best Pract Res Clin Endocrinol Metab 2012, 26:667-676.

14. Bollati V, Baccarelli A: Environmental epigenetics. Heredity (Edinb) 2010, 105:105-112.

15. Robison AJ, Nestler EJ: Transcriptional and epigenetic mechanisms of addiction. Nat Rev Neurosci 2012, 12:623-637.

16. Szyf M, McGowan P, Meaney MJ: The social environment and the epigenome. Environ Mol Mutagen 2008, 49:46-60.

17. Muller DJ, Likhodi O, Heinz A: Neural markers of genetic vulnerability to drug addiction. Curr Top Behav Neurosci 2010, 3:277-299.

18. Bierut L, Agrawal A, Bucholz KK, Doheny KF, Laurie C, Pugh E, Fisher S, Fox L, Howells W, Bertelsen S, Hinrichs AL, Almasy L, Breslau N, Culverhouse RC, Dick DM, Edenberg HJ, Foroud T, Grucza RA, Hatsukami D, Hesselbrock V, Johnson EO, Kramer J, Krueger RF, Kuperman S, Lynskey M, Mann K, Neuman RJ, Nothen MM, Nurnberger JI Jr, Porjesz B, Ridinger M, Saccone NL, Saccone SF, Schuckit MA, Tischfield JA, Wang JC, Rietschel M, Goate AM, Rice JP: A genome-wide association study of alcohol dependence. Proc Natl Acad Sci USA 2010, 107:5082-5087

19. Edenberg HJ, Koller DL, Xuei X, Wetherill L, McClintick JN, Almasy L, Bierut $\sqcup$, Bucholz KK, Goate A, Aliev F, Dick D, Hesselbrock V, Hinrichs A, Kramer J, Kuperman S, Nurnberger JI Jr, Rice JP, Schuckit MA, Taylor R, Todd Webb B, Tischfield JA, Porjesz B, Foroud T: Genome-wide association study of alcohol dependence implicates a region on chromosome 11. Alcohol Clin Exp Res 2010, 34:840-852.

20. Frank J, Cichon S, Treutlein J, Ridinger M, Mattheisen $M$, Hoffmann $P$, Herms S, Wodarz N, Soyka M, Zill P, Maier W, Mossner R, Gaebel W, Dahmen N, Scherbaum N, Schmal C, Steffens M, Lucae S, Ising M, Muller-Myhsok B, Nothen MM, Mann K, Kiefer F, Rietschel M: Genome-wide significant association between alcohol dependence and a variant in the $\mathrm{ADH}$ gene cluster. Addict Biol 2012, 17:171-180.

21. Heath AC, Whitfield JB, Martin NG, Pergadia ML, Goate AM, Lind PA, McEvoy BP, Schrage AJ, Grant JD, Chou YL, Zhu R, Henders AK, Medland SE, Gordon SD, Nelson EC, Agrawal A, Nyholt DR, Bucholz KK, Madden PA, Montgomery GW: A quantitative-trait genome-wide association study of alcoholism risk in the community: findings and implications. Biol Psychiatr 2011, 70:513-518.

22. Johnson C, Drgon T, Liu QR, Walther D, Edenberg H, Rice J, Foroud T, Uhl GR: Pooled association genome scanning for alcohol dependence using 104,268 SNPs: validation and use to identify alcoholism vulnerability loci in unrelated individuals from the collaborative study on the genetics of alcoholism. Am J Med Genet B Neuropsychiatr Genet 2006, 141B:844-853.

23. Kendler KS, Kalsi G, Holmans PA, Sanders AR, Aggen SH, Dick DM, Aliev F, Shi J, Levinson DF, Gejman PV: Genomewide association analysis of symptoms of alcohol dependence in the molecular genetics of schizophrenia (MGS2) control sample. Alcohol Clin Exp Res 2011, 35:963-975.

24. Lind PA, Macgregor S, Vink JM, Pergadia ML, Hansell NK, de Moor MH, Smit AB, Hottenga JJ, Richter MM, Heath AC, Martin NG, Willemsen G, de Geus EJ, Vogelzangs N, Penninx BW, Whitfield JB, Montgomery GW Boomsma DI, Madden PA: A genomewide association study of nicotine and alcohol dependence in Australian and Dutch populations. Twin Res Hum Genet 2010, 13:10-29.

25. Treutlein J, Cichon S, Ridinger M, Wodarz N, Soyka M, Zill P, Maier W, Moessner R, Gaebel W, Dahmen N, Fehr C, Scherbaum N, Steffens M, Ludwig KU, Frank J, Wichmann HE, Schreiber S, Dragano N, Sommer WH, Leonardi-Essmann F, Lourdusamy A, Gebicke-Haerter P, Wienker TF, Sullivan PF, Nothen MM, Kiefer F, Spanagel R, Mann K, Rietschel M: Genome-wide association study of alcohol dependence. Arch Gen Psychiatr 2009, 66:773-784.

26. Wang KS, Liu X, Zhang Q, Pan Y, Aragam N, Zeng M: A meta-analysis of two genome-wide association studies identifies 3 new loci for alcohol dependence. J Psychiatr Res 2011, 45:1419-1425.

27. Zuo L, Gelernter J, Zhang CK, Zhao H, Lu L, Kranzler HR, Malison RT, Li CS, Wang F, Zhang XY, Deng HW, Krystal JH, Zhang F, Luo X: Genome-wide association study of alcohol dependence implicates KIAA0040 on chromosome 1q. Neuropsychopharmacology 2012, 37:557-566.

28. Zuo L, Zhang CK, Wang F, Li CS, Zhao H, Lu L, Zhang XY, Zhang H, Zhang F, Krystal JH, Luo X: A novel, functional and replicable risk gene region for alcohol dependence identified by genome-wide association study. PLoS One 2011, 6:e26726.

29. Wang JC, Foroud T, Hinrichs AL, Le NX, Bertelsen S, Budde JP, Harari O, Koller DL, Wetherill L, Agrawal A, Almasy L, Brooks Al, Bucholz K, Dick D, Hesselbrock V, Johnson EO, Kang S, Kapoor M, Kramer J, Kuperman S, Madden PA, Manz N, Martin NG, McClintick JN, Montgomery GW, Nurnberger JI Jr, Rangaswamy M, Rice J, Schuckit M, Tischfield JA, Whitfield JB, Xuei X, Porjesz B, Heath AC, Edenberg HJ, Bierut LJ, Goate AM: A genome-wide association study of alcohol-dependence symptom counts in extended pedigrees identifies C15orf53. Mol Psychiatr 2012. Epub ahead of print.

30. Yan J, Aliev F, Webb BT, Kendler KS, Williamson VS, Edenberg HJ, Agrawal A, Kos MZ, Almasy L, Nurnberger JI Jr, Schuckit MA, Kramer JR, Rice JP, Kuperman S, Goate AM, Tischfield JA, Porjesz B, Dick DM: Using genetic information from candidate gene and genome-wide association studies in risk prediction for alcohol dependence. Addict Biol 2013. Epub ahead of print.

31. International Schizophrenia C, Purcell SM, Wray NR, Stone JL, Visscher PM, O'Donovan MC, Sullivan PF, Sklar P: Common polygenic variation contributes to risk of schizophrenia and bipolar disorder. Nature 2009, 460:748-752.

32. Covault J, Tennen H, Armeli S, Conner TS, Herman Al, Cillessen AH, Kranzler HR: Interactive effects of the serotonin transporter 5-HTTLPR polymorphism and stressful life events on college student drinking and drug use. Biol Psychiatr 2007, 61:609-616.

33. Kaufman J, Yang BZ, Douglas-Palumberi H, Crouse-Artus M, Lipschitz D, Krystal JH, Gelernter J: Genetic and environmental predictors of early alcohol use. Biol Psychiatr 2007, 61:1228-1234.

34. Laucht M, Treutlein J, Schmid B, Blomeyer D, Becker K, Buchmann AF, Schmidt MH, Esser G, Jennen-Steinmetz C, Rietschel M, Zimmermann US, Banaschewski T: Impact of psychosocial adversity on alcohol intake in young adults: moderation by the LL genotype of the serotonin transporter polymorphism. Biol Psychiatr 2009, 66:102-109.

35. Nilsson KW, Sjoberg RL, Damberg M, Alm PO, Ohrvik J, Leppert J, Lindstrom L, Oreland L: Role of the serotonin transporter gene and family function in adolescent alcohol consumption. Alcohol Clin Exp Res 2005, 29:564-570.

36. Bau CH, Almeida S, Hutz MH: The Taql A1 allele of the dopamine D2 receptor gene and alcoholism in Brazil: association and interaction with stress and harm avoidance on severity prediction. Am J Med Genet 2000, 96:302-306.

37. Madrid GA, MacMurray J, Lee JW, Anderson BA, Comings DE: Stress as a mediating factor in the association between the DRD2 Taql polymorphism and alcoholism. Alcohol 2001, 23:117-122.

38. van der Zwaluw CS, Engels RC, Vermulst AA, Franke B, Buitelaar J, Verkes RJ, Scholte $\mathrm{RH}$ : Interaction between dopamine D2 receptor genotype and parental rule-setting in adolescent alcohol use: evidence for a gene-parenting interaction. Mol Psychiatr 2010, 15:727-735.

39. Laucht M, Blomeyer D, Buchmann AF, Treutlein J, Schmidt MH, Esser G, Jennen-Steinmetz C, Rietschel M, Zimmermann US, Banaschewski T: Catechol-O-methyltransferase Val158 Met genotype, parenting practices and adolescent alcohol use: testing the differential susceptibility hypothesis. J Child Psychol Psychiatr 2012, 53:351-359.

40. Schellekens AF, Franke B, Ellenbroek B, Cools A, de Jong CA, Buitelaar JK, Verkes RJ: COMT Val158Met modulates the effect of childhood adverse experiences on the risk of alcohol dependence. Addict Biol 2013, 18:344-356

41. Nilsson KW, Sjoberg RL, Wargelius HL, Leppert J, Lindstrom L, Oreland L: The monoamine oxidase A (MAO-A) gene, family function and maltreatment as predictors of destructive behaviour during male adolescent alcohol consumption. Addiction 2007, 102:389-398.

42. Nilsson KW, Wargelius HL, Sjoberg RL, Leppert J, Oreland L: The MAO-A gene, platelet MAO-B activity and psychosocial environment in adolescent female alcohol-related problem behaviour. Drug Alcohol Depend 2008, 93:51-62.

43. Nilsson KW, Comasco E, Aslund C, Nordquist N, Leppert J, Oreland L: MAOA genotype, family relations and sexual abuse in relation to adolescent alcohol consumption. Addict Biol 2011, 16:347-355.

44. Dick DM, Agrawal A, Schuckit MA, Bierut L, Hinrichs A, Fox L, Mullaney J, Cloninger CR, Hesselbrock V, Nurnberger J Jr, Almasy L, Foroud T, Porjesz B, Edenberg $H$, Begleiter $H$ : Marital status, alcohol dependence, and 
GABRA2: evidence for gene-environment correlation and interaction. J Stud Alcohol 2006, 67:185-194.

45. Blomeyer D, Treutlein J, Esser G, Schmidt MH, Schumann G, Laucht M: Interaction between CRHR1 gene and stressful life events predicts adolescent heavy alcohol use. Biol Psychiatr 2008, 63:146-151.

46. Nelson EC, Agrawal A, Pergadia ML, Wang JC, Whitfield JB, Saccone FS, Kern J, Grant JD, Schrage AJ, Rice JP, Montgomery GW, Heath AC, Goate AM, Martin NG, Madden PA: H2 haplotype at chromosome 17q21.31 protects against childhood sexual abuse-associated risk for alcohol consumption and dependence. Addict Biol 2010, 15:1-11.

47. Schmid B, Blomeyer D, Treutlein J, Zimmermann US, Buchmann AF, Schmidt MH, Esser G, Rietschel M, Banaschewski T, Schumann G, Laucht M: Interacting effects of CRHR1 gene and stressful life events on drinking initiation and progression among 19-year-olds. Int J Neuropsychopharmacol 2010, 13:703-714.

48. Ray LA, Sehl M, Bujarski S, Hutchison K, Blaine S, Enoch MA: The Crhr1 Gene, Trauma Exposure, And Alcoholism Risk: A Test Of G x E Effects. Genes Brain Behav 2013. Epub ahead of print.

49. Robison AJ, Nestler EJ: Transcriptional and epigenetic mechanisms of addiction. Nat Rev Neurosci 2011, 12:623-637.

50. Bleich S, Degner D, Javaheripour K, Kurth C, Kornhuber J: Homocysteine and alcoholism. J Neural Transm Supp/ 2000, 60:187-196.

51. Bleich S, Degner D, Wiltfang J, Maler JM, Niedmann P, Cohrs S, Mangholz A, Porzig J, Sprung R, Ruther E, Kornhuber J: Elevated homocysteine levels in alcohol withdrawal. Alcohol Alcohol 2000, 35:351-354.

52. Cravo ML, Gloria LM, Selhub J, Nadeau MR, Camilo ME, Resende MP, Cardoso JN, Leitao CN, Mira FC: Hyperhomocysteinemia in chronic alcoholism: correlation with folate, vitamin B-12, and vitamin B-6 status. Am J Clin Nutr 1996, 63:220-224.

53. Hultberg B, Berglund $M$, Andersson A, Frank A: Elevated plasma homocysteine in alcoholics. Alcohol Clin Exp Res 1993, 17:687-689.

54. Heese $P$, Linnebank $M$, Semmler A, Muschler MA, Heberlein A, Frieling $H$, Stoffel-Wagner B, Kornhuber J, Banger M, Bleich S, Hillemacher T: Alterations of homocysteine serum levels during alcohol withdrawal are influenced by folate and riboflavin: results from the German Investigation on Neurobiology in Alcoholism (GINA). Alcohol Alcohol 2012, 47:497-500

55. Bleich S, Hillemacher T: Homocysteine, Alcoholism and its Molecular Networks. Pharmacopsychiatry 2009, 42:S102-S109.

56. Shukla SD, Velazquez J, French SW, Lu SC, Ticku MK, Zakhari S: Emerging role of epigenetics in the actions of alcohol. Alcohol Clin Exp Res 2008, 32:1525-1534

57. Bonsch D, Lenz B, Reulbach U, Kornhuber J, Bleich S: Homocysteine associated genomic DNA hypermethylation in patients with chronic alcoholism. J Neural Transm 2004, 111:1611-1616.

58. Bonsch D, Lenz B, Fiszer R, Frieling H, Kornhuber J, Bleich S: Lowered DNA methyltransferase (DNMT-3b) mRNA expression is associated with genomic DNA hypermethylation in patients with chronic alcoholism. J Neural Transm 2006, 113:1299-1304.

59. Ingrosso D, Perna AF: Epigenetics in hyperhomocysteinemic states. A special focus on uremia. Biochim Biophys Acta 2009, 1790:892-899.

60. Castro R, Rivera I, Struys EA, Jansen EE, Ravasco P, Camilo ME, Blom HJ, Jakobs C, Tavares de Almeida I: Increased homocysteine and S-adenosylhomocysteine concentrations and DNA hypomethylation in vascular disease. Clin Chem 2003, 49:1292-1296.

61. Yi P, Melnyk S, Pogribna M, Pogribny IP, Hine RJ, James SJ: Increase in plasma homocysteine associated with parallel increases in plasma S-adenosylhomocysteine and lymphocyte DNA hypomethylation. J Biol Chem 2000, 275:29318-29323.

62. Ingrosso D, Cimmino A, Perna AF, Masella L, De Santo NG, De Bonis ML, Vacca M, D'Esposito M, D'Urso M, Galletti P, Zappia V: Folate treatment and unbalanced methylation and changes of allelic expression induced by hyperhomocysteinaemia in patients with uraemia. Lancet 2003, 361:1693-1699.

63. Bonsch D, Hothorn T, Krieglstein C, Koch M, Nehmer C, Lenz B, Reulbach U, Kornhuber J, Bleich S: Daily variations of homocysteine concentration may influence methylation of DNA in normal healthy individuals. Chronobiol Int 2007, 24:315-326.

64. Zhang H, Herman Al, Kranzler HR, Anton RF, Simen AA, Gelernter J: Hypermethylation of OPRM1 promoter region in European Americans with alcohol dependence. J Hum Genet 2012, 57:670-675.
65. Biermann $T$, Reulbach $U$, Lenz B, Frieling $H$, Muschler M, Hillemacher $T$, Kornhuber J, Bleich S: N-methyl-D-aspartate $2 \mathrm{~b}$ receptor subtype (NR2B) promoter methylation in patients during alcohol withdrawal. J Neural Transm 2009, 116:615-622.

66. Bleich S, Lenz B, Ziegenbein M, Beutler S, Frieling H, Kornhuber J, Bonsch D: Epigenetic DNA hypermethylation of the HERP gene promoter induces down-regulation of its mRNA expression in patients with alcohol dependence. Alcohol Clin Exp Res 2006, 30:587-591.

67. Bonsch D, Lenz B, Kornhuber J, Bleich S: DNA hypermethylation of the alpha synuclein promoter in patients with alcoholism. Neuroreport 2005, 16:167-170.

68. Heberlein A, Muschler M, Frieling H, Behr M, Eberlein C, Wilhelm J, Groschl M, Kornhuber J, Bleich S, Hillemacher T: Epigenetic down regulation of nerve growth factor during alcohol withdrawal. Addict Biol 2011, 18:508-510.

69. Nieratschker V, Grosshans M, Frank J, Strohmaier J, von der Goltz C, El-Maarri O, Witt SH, Cichon S, Nothen MM, Kiefer F, Rietschel M: Epigenetic alteration of the dopamine transporter gene in alcohol-dependent patients is associated with age. Addict Biol 2012. Epub ahead of print.

70. Hillemacher T, Frieling H, Hartl T, Wilhelm J, Kornhuber J, Bleich S: Promoter specific methylation of the dopamine transporter gene is altered in alcohol dependence and associated with craving. J Psychiatr Res 2009, 43:388-392.

71. Hillemacher T, Frieling H, Luber K, Yazici A, Muschler MA, Lenz B, Wilhelm J, Kornhuber J, Bleich S: Epigenetic regulation and gene expression of vasopressin and atrial natriuretic peptide in alcohol withdrawal. Psychoneuroendocrinology 2009, 34:555-560.

72. Philibert RA, Gunter TD, Beach SR, Brody GH, Madan A: MAOA methylation is associated with nicotine and alcohol dependence in women. Am J Med Genet B Neuropsychiatr Genet 2008, 147B:565-570.

73. Philibert RA, Sandhu H, Hollenbeck N, Gunter T, Adams W, Madan A: The relationship of $5 \mathrm{HTT}$ (SLC6A4) methylation and genotype on mRNA expression and liability to major depression and alcohol dependence in subjects from the lowa Adoption Studies. Am J Med Genet B Neuropsychiatr Genet 2008, 147B:543-549.

74. Muschler MA, Hillemacher T, Kraus C, Kornhuber J, Bleich S, Frieling H: DNA methylation of the POMC gene promoter is associated with craving in alcohol dependence. J Neural Transm 2010, 117:513-519.

75. Taqi MM, Bazov I, Watanabe H, Sheedy D, Harper C, Alkass K, Druid H, Wentzel P, Nyberg F, Yakovleva T, Bakalkin G: Prodynorphin CpG-SNPs associated with alcohol dependence: elevated methylation in the brain of human alcoholics. Addict Biol 2011, 16:499-509.

76. Zhang H, Herman Al, Kranzler HR, Anton RF, Zhao H, Zheng W, Gelernter J: Array-based profiling of DNA methylation changes associated with alcohol dependence. Alcohol Clin Exp Res 2013, 37(Suppl 1):E108-E115.

77. Philibert RA, Plume JM, Gibbons FX, Brody GH, Beach SR: The impact of recent alcohol use on genome wide DNA methylation signatures. Front Genet 2012, 3:54

78. Zhang R, Miao Q, Wang C, Zhao R, Li W, Haile CN, Hao W, Zhang XY: Genome-wide DNA methylation analysis in alcohol dependence. Addict Biol 2013, 18:392-403.

79. Wedekind D, Neumann K, Falkai P, Malchow B, Engel KR, Jamrozinski K, Havemann-Reinecke U: S100B and homocysteine in the acute alcohol withdrawal syndrome. Eur Arch Psychiatr Clin Neurosci 2011, 261:133-138.

doi:10.1186/2049-9256-1-11

Cite this article as: Nieratschker et al:: Genetics and epigenetics of alcohol dependence. Journal of Molecular Psychiatry 2013 1:11. 